
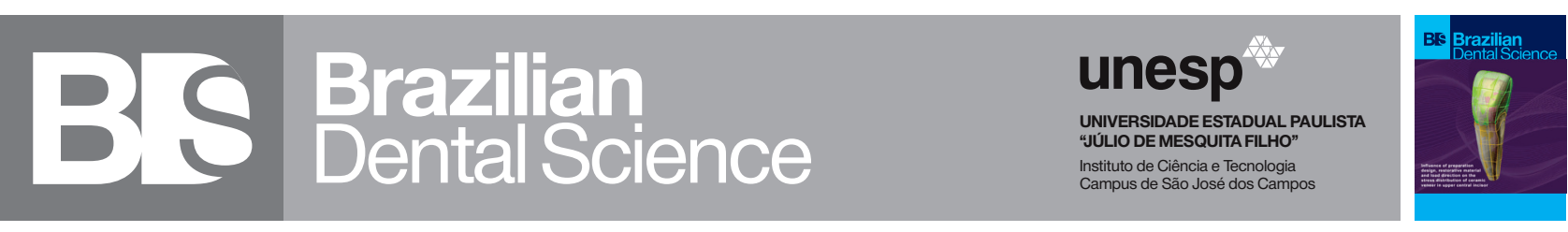

\title{
The Effect of GaAlAs Laser, Sandblasting, and Primers on Bond Strength between Zirconia Ceramic and Direct Resin Composite after Thermocycling
}

O efeito do laser de GaAlAs, jateamento e primers na resistência de união entre cerâmica de zircônia e resina composta direta após termociclagem

Boonlert KUKIATTRAKOON ${ }^{1}$, Pitchaporn KOSAGO ${ }^{2}$

1 - Prince of Songkla University, Department of Conservative Dentistry and Dental Materials Research Unit (Second phase), Hat Yai, Songkhla.

2 - Prince of Songkla University, Department of Conservative Dentistry, Hat Yai, Songkhla.

\section{ABSTRACT}

Objective: This study was conducted to evaluate the shear bond strength (SBS) of resin composite on zirconia ceramic after different surface treatments and thermocycling. Material and Methods: Two hundred and seven zirconia specimens were divided into 9 groups and treated as follows: Group C-no treatment (served as the control); Group PC-Clearfil Ceramic primer (CP); Group PZ-Z-Prime Plus primer (ZP); Group A-sandblasted with $50 \mu \mathrm{m} \mathrm{Al} 2 \mathrm{O} 3$ at $0.25 \mathrm{MPa}$ for $20 \mathrm{~s}$ at a distance of $10 \mathrm{~mm}$; Group AC-sandblasted and coated with CP; Group AZ-sandblasted and coated with ZP; Group L-GaAlAs diode laser with $808 \pm 5 \mathrm{~mm}$ wavelength, 3 watts power, and $10 \mathrm{~Hz}$ frequency; Group LC-GaAlAs diode laser coated with CP; and Group LZ-GaAlAs diode laser coated with ZP. All specimens were directly bonded with a resin composite cylinder using Adper Scotchbond Multipurpose. Specimens were stored at $37^{\circ} \mathrm{C}$ for 30 days and subjected to 2,500 thermocycles from $5^{\circ} \mathrm{C}$ and $55^{\circ} \mathrm{C}$ before the SBS was performed. One-way ANOVA and Tukey's HSD test $(\alpha=0.05)$ were performed. Surface topography changes were evaluated with a scanning electron microscope (SEM). Results: Sandblasting combined with CP or ZP $(25.08 \pm 0.86$ and $24.78 \pm 0.13 \mathrm{MPa}$, respectively) yielded the highest SBS and was significantly different from other methods ( $p<0.05)$. SEM showed various degrees of changes depending on different surface treatments. Conclusion: Surface treatment by sandblasting combined with a CP or ZP significantly provide the highest SBS between zirconia and resin composite.

\section{KEYWORDS}

Bond strength; Resin composite; Surface treatment; Zirconia ceramic.

\section{RESUMO}

Objetivo: Este estudo foi conduzido para avaliar a resistência ao cisalhamento (SBS) de resina composta em cerâmica de zircônia após diferentes tratamentos de superfície e termociclagem. Material e Métodos: Duzentos e sete espécimes de zircônia foram divididos em 9 grupos e tratados da seguinte forma: Grupo C- sem tratamento (serviu como controle); Grupo PC-Clearfil Ceramic primer (CP); Grupo PZ-Z-Prime Plus primer (ZP); Grupo A - jateado com $50 \mu \mathrm{m}$ de $\mathrm{Al} 2 \mathrm{O} 3$ a 0,25 MPa por $20 \mathrm{~s}$ a uma distância de $10 \mathrm{~mm}$; Grupo AC - jateado e revestido com CP; Grupo AZ - jateado e revestido com ZP; Grupo L - Laser de diodo GaAlAs com comprimento de onda de $808 \pm 5 \mathrm{~mm}$, potência de 3 watts e frequência de $10 \mathrm{~Hz}$; Grupo LC -Laser de diodo GaAlAs revestido com CP; e Grupo LZ - Laser de diodo GaAlAs revestido com ZP. Todos os espécimes foram diretamente colados com um cilindro de resina composta usando Adper Scotchbond Multi-purpose. As amostras foram armazenadas a $37^{\circ} \mathrm{C}$ por 30 dias e submetidas a 2.500 termociclos de $5^{\circ} \mathrm{C}$ e $55^{\circ} \mathrm{C}$ antes da realização do SBS. ANOVA unilateral e teste HSD de Tukey $(\alpha=0,05)$ foram realizados. As mudanças na topografia da superfície foram avaliadas com um microscópio eletrônico de varredura (MEV). Resultados: $\mathrm{O}$ jato de areia combinado com CP ou ZP $(25,08 \pm 0,86$ e $24,78 \pm 0,13 \mathrm{MPa}$, respectivamente) rendeu o maior SBS e foi significativamente diferente dos outros métodos $(\mathrm{p}<0,05)$. SEM mostrou vários graus de mudanças dependendo dos diferentes tratamentos de superfície. Conclusão: $\mathrm{O}$ tratamento de superfície por jato de areia combinado com um CP ou ZP fornece significativamente o maior SBS entre a zircônia e a resina composta.

\section{PALAVRAS-CHAVE}

Força de união; Resina composta; Tratamento da superfície; Cerâmica de zircônia. 


\section{INTRODUCTION}

Z irconia ceramics have been used in dentistry since the early 1990s as prefabricated posts, implants, and substructures for crown and fixed partial dentures. Zirconia ceramics have been filled with $2-3$ mol\% yttrium oxide, resulting in a tetragonal phase at room temperature. So, this type of zirconia ceramic is called yittriumtetragonal zirconia polycrystal: Y-TZP. However, tetragonal exists in a metastable phase, which stores energy within the material and drives the phase transition from the tetragonal to monoclinic phase when stimulated. This phenomenon is called transformation toughening and results in an increasing of 3-5 per cent in volume of zirconia ceramic, causing compressive force around the crack and crack tip, and reduces or stops the propagation of cracks. The result of this phenomenon, which is not seen in other ceramics including the structure of packed crystalline ceramics, brings higher mechanical properties of zirconia ceramic than other ceramic types [1].

However, failure range up to $44 \%$ [2], and has been found in zirconia ceramic due to fractures in the veneering ceramic, either in the veneering layer or exposed zirconia substructure (bi-layered restoration) [3]. Several methods were usually searched by dentists for expanding the service life of existing restorations since restoration replacement can conduct for additional costs for patients. For this task, repairing of the fractured ceramic intraorally with a resin composite is the most commonly used method.

The success of the repairing task with resin composite is largely determined by the ability to adhere to the surface of the veneering layer or zirconia ceramic substructure. Hydrofluoric (HF) acid etching is a well accepted pre-treatment for bonding veneering ceramic surface layers [4] but not for zirconia ceramic substructures. Surface treatment of zirconia ceramic includes sandblasting with $50 \mu \mathrm{m}$ aluminium oxide [5], priming with MDP primer [6], a combination of sandblasting and MDP primer, silica coating [7], and CO2, Nd:YAG or Er:YAG laser [8-11]. While previous studies have shown that diode (GaAlAs) lasers alone do not roughen the zirconia ceramic surface $[12,13]$. The question arose whether the increased wattage or time duration of a diode laser combined with a primer improved the bond strength or not.

However, most research has been developed and conducted to treat the zirconia surface for indirect bonding with resin cement. Few studies for intraoral repair of zirconia ceramics with direct resin composite and thermocycles have been found. Therefore, the aims of this study were to investigate the effect of different surface treatments of zirconia ceramic for bonding with direct resin composite after thermocycling to achieve the optimal treatment and to examine the changes of zirconia surfaces after the treatments.

\section{MATERIAL AND METHODS}

\section{Specimen Preparation}

The materials used in this study and their compositions are shown in Table I. Two hundred and seven specimens were prepared according to the manufacturer's instructions. Briefly, zirconia ceramic blocks (IPS e.max ZirCAD MO block, Ivoclar Vivadent AG, Schaan, Liechtenstein) were cut with a precision saw (ISOMET 4000, Buehler, Lake Bluff, IL, USA) to specimens with $12 \mathrm{~mm}$ width, $12 \mathrm{~mm}$ length and $4 \mathrm{~mm}$ thickness. Crack specimens were detected under 10x magnification using a stereomicroscope (model SMZ 1500m, Nikon Instech, Kanagawa, Japan) and were excluded from the experiment. Specimens were then processed by heating to $1,500^{\circ} \mathrm{C}$ for $8 \mathrm{~h}$ (Progamat S1 high-temperature furnace, Ivoclar Vivadent AG, Schaan, Liechtenstein). Subsequently, sintered specimens with a final dimension of $9.6 \mathrm{~mm}$ width, $9.6 \mathrm{~mm}$ length and $3.2 \mathrm{~mm}$ thickness ( $18.5 \%$ to $19.6 \%$ shrinkage) were embedded in autopolymerizing clear acrylic resin (Takilon, Rodont srl, Milan, Italy), $30 \mathrm{~mm}$ in height and $30 \mathrm{~mm}$ in diameter. The specimens were then polished (model Phoenix 4000, Buehler GmbH, Düsseldorf, Germany) under running water using 600- and 1,200-grit silicon carbide paper (3M ESPE, St. Paul, MN, USA).

The specimens were randomly divided into 9 groups of 23 specimens each. The surface treatment performed on each group was as follows: 

treatment).

Group C was the control group (no

Group PC was coated with primer (Clearfil Ceramic Primer, Kuraray, Tokyo, Japan) for $20 \mathrm{~s}$ and air-dried for $20 \mathrm{~s}$.

Group PZ was coated with primer (Z-Prime Plus, Bisco, Schaumburg, IL, USA) for $20 \mathrm{~s}$ and air-dried for $20 \mathrm{~s}$.

Group $S$ was sandblasted (Sandblaster, Dental Farm, Torino, Italy) with $50 \mu \mathrm{m} \mathrm{Al}_{2} \mathrm{O}_{3}$ at $0.25 \mathrm{MPa}$ for $20 \mathrm{~s}$ at a distance of $10 \mathrm{~mm}$ and dried.

Group SC was sandblasted (Sandblaster, Dental Farm, Torino, Italy) with $50 \mu \mathrm{m} \mathrm{Al}_{2} \mathrm{O}_{3}$ at $0.25 \mathrm{MPa}$ for $20 \mathrm{~s}$ at a distance of $10 \mathrm{~mm}$ and dried. Primer (Clearfil Ceramic Primer, Kuraray, Tokyo, Japan) was then coated for $20 \mathrm{~s}$ and airdried for $20 \mathrm{~s}$.

Group SZ was sandblasted (Sandblaster, Dental Farm, Torino, Italy) with $50 \mu \mathrm{m} \mathrm{Al}_{2} \mathrm{O}_{3}$ at $0.25 \mathrm{MPa}$ for $20 \mathrm{~s}$ at a distance of $10 \mathrm{~mm}$ and dried. Primer (Z-Prime Plus, Bisco, Schaumburg, IL, USA) was then coated for $20 \mathrm{~s}$ and air-dried for $20 \mathrm{~s}$.

Group L was treated with a diode laser (GaAlAs Laser Diode, model SL3, Philips Oral Healthcare-LA, CA, USA) with $808 \pm 5 \mathrm{~nm}$ wavelength, 3 watts power, and $10 \mathrm{~Hz}$ frequency for $2 \mathrm{~min}$ (modified from Kriebel [14]).

Group LC was treated with a diode laser (GaAlAs Laser Diode, model SL3, Philips Oral Healthcare-LA, CA, USA) with $808 \pm 5 \mathrm{~nm}$ wavelength, 3 watts power, and $10 \mathrm{~Hz}$ frequency for 2 min (modified from Kriebel [14]). Primer (Clearfil Ceramic Primer, Kuraray, Tokyo, Japan) was then applied for $20 \mathrm{~s}$ and air-dried for $20 \mathrm{~s}$.

Group LZ was treated with a diode laser (GaAlAs Laser Diode, model SL3, Philips Oral Healthcare-LA, CA, USA) with $808 \pm 5 \mathrm{~nm}$ wavelength, 3 watts power, and $10 \mathrm{~Hz}$ frequency for $2 \mathrm{~min}$ (modified from Kriebel [14]). Primer (Z-Prime Plus, Bisco, Schaumburg, IL, USA) was then applied for $20 \mathrm{~s}$ and air-dried for $20 \mathrm{~s}$.

\section{Bonding Procedures}

For direct bonding with resin composite, the zircomia specimens were applied with a bonding agent (Adper Scotchbond Multi-Purpose Plus Adhesive, 3M ESPE, St.Paul, MN, USA) and light-polymerized with visible light $(600 \mathrm{~mW} /$ $\mathrm{cm}^{2}$ at a wavelength of 400 to $500 \mathrm{~nm}$; XL3000, 3M ESPE, St.Paul, MN, USA) for $20 \mathrm{~s}$.

A thin plastic tube (AP Extrusion, Salem, $\mathrm{NH}, \mathrm{USA}$ ) with $4 \mathrm{~mm}$ inner diameter and $2 \mathrm{~mm}$ thickness was placed and held at the center of each zirconia specimen with plastic pliers. The tube was filled in with resin composite (Filtek Z250XT, 3M ESPE, St.Paul, MN, USA) and light-polymerized for $40 \mathrm{~s}$, and again for $40 \mathrm{~s}$ after the plastic tube had been cut with a blade and removed. All specimens were stored in $100 \%$ humidity at $37^{\circ} \mathrm{C}$ for 30 days with 2,500 thermocycles from $5^{\circ} \mathrm{C}$ and $55^{\circ} \mathrm{C}$ before shear bond strength testing was performed.

\section{Shear Bond Strength Testing}

The shear bond strength of resin composite on the zirconia specimens was tested by using a single-bladed Instron Machine (model 5583, Instron Corp., Norwood, MA, USA) at a crosshead speed of $0.2 \mathrm{~mm} / \mathrm{min}$ [15]. The load at failure was recorded and converted to shear bond strength expressed in MegaPascals ( $\mathrm{MPa}$ ) as in the following formula:

\section{Shear bond strength $=\mathrm{F} / \mathrm{Tr}^{2}$}

where $\mathrm{F}$ is a load force at fracture in Newtons and $r$ is the radius of the resin composite cylinder in meters. The surfaces of the specimens were subsequently examined under a stereoscope (model SMZ 1500m, Nikon Instech, Kanagawa, Japan) at $\mathrm{x} 50$ magnification in order to determine the mode of failure. Mode of failure was recorded by one observer as either adhesive (between zirconia or resin composite and bonding agent), cohesive (in the zirconia, resin composite or bonding agent) or a combination of adhesive and cohesive fractures [13].

\section{Surface Topography Analysis}

Twenty seven ceramic specimens, three from each group, were selected to investigate the treated surface topography. The specimens were rinsed with distilled water for $20 \mathrm{~s}$, dried and mounted onto aluminium stubs (13 mm diameter 
and $10 \mathrm{~mm}$ height). Subsequently, specimens were sputter-coated with a gold-palladium alloy (SPI-Module sputter, SPI Supplies, West Chester, PA, USA). Observations were made under a scanning electron microscope (SEM) (model JSM-5800LV, JEOL, Tokyo, Japan) at x1000 magnification.

\section{Statistical Analysis}

Data were statistically analyzed. A one-way analysis of variance (ANOVA) was used to find differences between groups. Tukey's Honestly Significant Difference (HSD) Test was used for post hoc comparisons $(\alpha=0.05)$.

\section{RESULTS}

Results of the one-way ANOVA revealed that the shear bond strength differed significantly between groups $(p<0.05)$. The mean values of the shear bond strength of resin composite on the zirconia at the fracture, as well as the results of multiple comparisons using Tukey's HSD tests, are presented in Table II. Sandblasting combined with Clearfil Ceramic primer or Z-Prime Plus primer $(25.08 \pm 0.86$ and $24.78 \pm 0.13 \mathrm{MPa}$, respectively) yielded the highest SBS and were significantly different from other methods ( $\mathrm{p}<$ 0.05).

SEM images of the differently treated zirconia surfaces are shown in Figure 1. Surfaces of the specimens in the control and laser groups showed scratches and grooves (Figures 1A and $1 \mathrm{G})$. Specimens treated with sandblasting produced noticeable changes on the zirconia ceramic surface (Figure 1D), in which irregular porous surfaces with various micro-undercuts were observed over the entire surface. Specimens coated with primers presented thin layer covered.

The mode of failure of all specimen groups, evaluated under a stereoscope, was shown in Table III. Adhesive failure was noticeable in all groups in varying numbers. Combination failure was found in C, SC, and SZ groups.
Table I - Materials used in this present study

\begin{tabular}{|c|c|c|}
\hline Product & Composition & Manufacturer \\
\hline IPS e.max ZirCAD M0 & $\begin{array}{c}\mathrm{ZrO} \mathrm{O}_{2}(88-95.5 \%), \mathrm{Y}_{2} \mathrm{O}_{3}(4.5-6 \%) \\
\mathrm{HfO2}(5 \%), \mathrm{Al}_{2} \mathrm{O}_{3}(1 \%),\end{array}$ & $\begin{array}{l}\text { Ivoclar Vivadent AG, Schaan, } \\
\text { Liechtenstein }\end{array}$ \\
\hline Clearfil Ceramic Primer & $\begin{array}{l}\text { 3-Methacryloxypropil trimethoxy } \\
\text { silane, MDP,Ethanol }\end{array}$ & Kuraray, Tokyo, Japan \\
\hline Z-Prime Plus & $\begin{array}{l}\text { Organophosphate monomer, } \\
\text { carboxylic acid monomer, HEMA, } \\
\text { ethanol }\end{array}$ & Bisco, Schaumburg, L, USA \\
\hline $\begin{array}{l}\text { Scotchbond Multi } \\
\text { Purpose Plus }\end{array}$ & Bis-GMA, HEMA, Tertiary Amines & 3MESPE, St. Paul, MN, USA \\
\hline Filtek Z350XT & $\begin{array}{l}\text { Bis-EMA, Bis-GMA, TEGDMA, } \\
\text { UDMA, zirconia, silica }\end{array}$ & 3M ESPE, St. Paul, MN, USA \\
\hline
\end{tabular}

$\mathrm{ZrO}_{2}$ : Zirconium dioxide, $\mathrm{Y}_{2} \mathrm{O}_{3}$ : Yttrium oxide, $\mathrm{HfO}_{2}$ : Hafnium oxide, 10-MDP: 10-Methacryloyloxydecyl dihydrogen phosphate, HEMA: 2-hydroxyethyl methacrylate, Bis-GMA: Bisphenol A diglycidyl methacrylate, Bis-EMA: ethoxylated bisphenol A glycol dimethacrylate, TEGDMA: triethylene glycol dimethacrylate, UDMA: urethane dimethacrylate.

Table II - Mean shear bond strength \pm SD of zirconia ceramics to resin composites in MPa after ANOVA One-Way and Tukey test ( $5 \%$ of significance)

\begin{tabular}{|ccc|}
\hline Group & Surface treatment & Mean shear bond strength \pm SD \\
\hline C & Control (no treatment) & $6.02 \pm 0.98^{\mathrm{a}}$ \\
\hline PC & Clearfil Ceramic Primer & $16.1 \pm 0.82^{\circ}$ \\
\hline PZ & Z-Prime Plus & $14.65 \pm 0.73^{c}$ \\
\hline S & Sandblasting with $50 \mu \mathrm{ml}_{2} \mathrm{O}_{3}$ & $15.24 \pm 0.16^{\mathrm{c}}$ \\
\hline SC & $\begin{array}{c}\text { Sandblasting with } 50 \mu \mathrm{m} \mathrm{Al}_{2} \mathrm{O}_{3}+ \\
\text { Clearfil Ceramic Primer }\end{array}$ & $25.08 \pm 0.86^{d}$ \\
\hline SZ & $\begin{array}{c}\text { Sandblasting with } 50 \mu \mathrm{m} \mathrm{Al} \mathrm{Al}_{3}+ \\
\text { Z-Prime Plus }\end{array}$ & $24.78 \pm 0.13^{d}$ \\
\hline L & GaAIAs Diode Laser & $8.02 \pm 0.07^{\circ}$ \\
\hline LC & GaAlAs Diode Laser + Clearfil & $16.07 \pm 0.72^{\circ}$ \\
\hline LZ & Ceramic Primer & $14.66 \pm 0.85^{\circ}$ \\
\hline
\end{tabular}

a-d Group identified with different letters were significantly different $(p<0.05)$.

Table III - Mode of failure after shear bond strength testing

\begin{tabular}{|c|c|c|c|c|}
\hline \multirow{2}{*}{$\begin{array}{l}\text { Group and surface treat- } \\
\text { ment }\end{array}$} & \multicolumn{3}{|c|}{ Type of failure } & \multirow{2}{*}{ Total } \\
\hline & Adhesive & Cohesive & Combination & \\
\hline C:Control (no treatment) & 20 & 0 & 0 & 20 \\
\hline PC:Clearfil Ceramic Primer & 18 & 0 & 2 & 20 \\
\hline PZ:Z-Prime Plus & 20 & 0 & 0 & 20 \\
\hline $\mathrm{S}:$ Sandblasting with $50 \mu \mathrm{m} \mathrm{Al}_{2} \mathrm{O}_{3}$ & 20 & 0 & 0 & 20 \\
\hline $\begin{array}{l}\text { SC: Sandblasting with } 50 \mu \mathrm{m} \\
\mathrm{Al}_{2} \mathrm{O}_{3}+\text { Clearfil Ceramic Primer }\end{array}$ & 2 & 0 & 18 & 20 \\
\hline $\begin{array}{l}\text { SZ: Sandblasting with } 50 \mu \mathrm{m} \\
\quad \mathrm{Al}_{2} \mathrm{O}_{3}+\mathrm{Z} \text {-Prime Plus }\end{array}$ & 2 & 0 & 18 & 20 \\
\hline L:GaAlAs Diode Laser & 20 & 0 & 0 & 20 \\
\hline $\begin{array}{l}\text { LC: GaAlAs Diode Laser + Clearfil } \\
\text { Ceramic Primer }\end{array}$ & 20 & 0 & 0 & 20 \\
\hline $\begin{array}{l}\text { LZ:GaAlAs Diode Laser + } \\
\text { Z-Prime Plus }\end{array}$ & 20 & 0 & 0 & 20 \\
\hline
\end{tabular}




\begin{tabular}{|c|c|}
\hline Kukiattrakoon B et al. & $\begin{array}{l}\text { The Effect of GaAIAs Laser, Sandblasting, and Primers on Bond Strength } \\
\text { between Zirconia Ceramic and Direct Resin Composite after Thermocycling }\end{array}$ \\
\hline
\end{tabular}
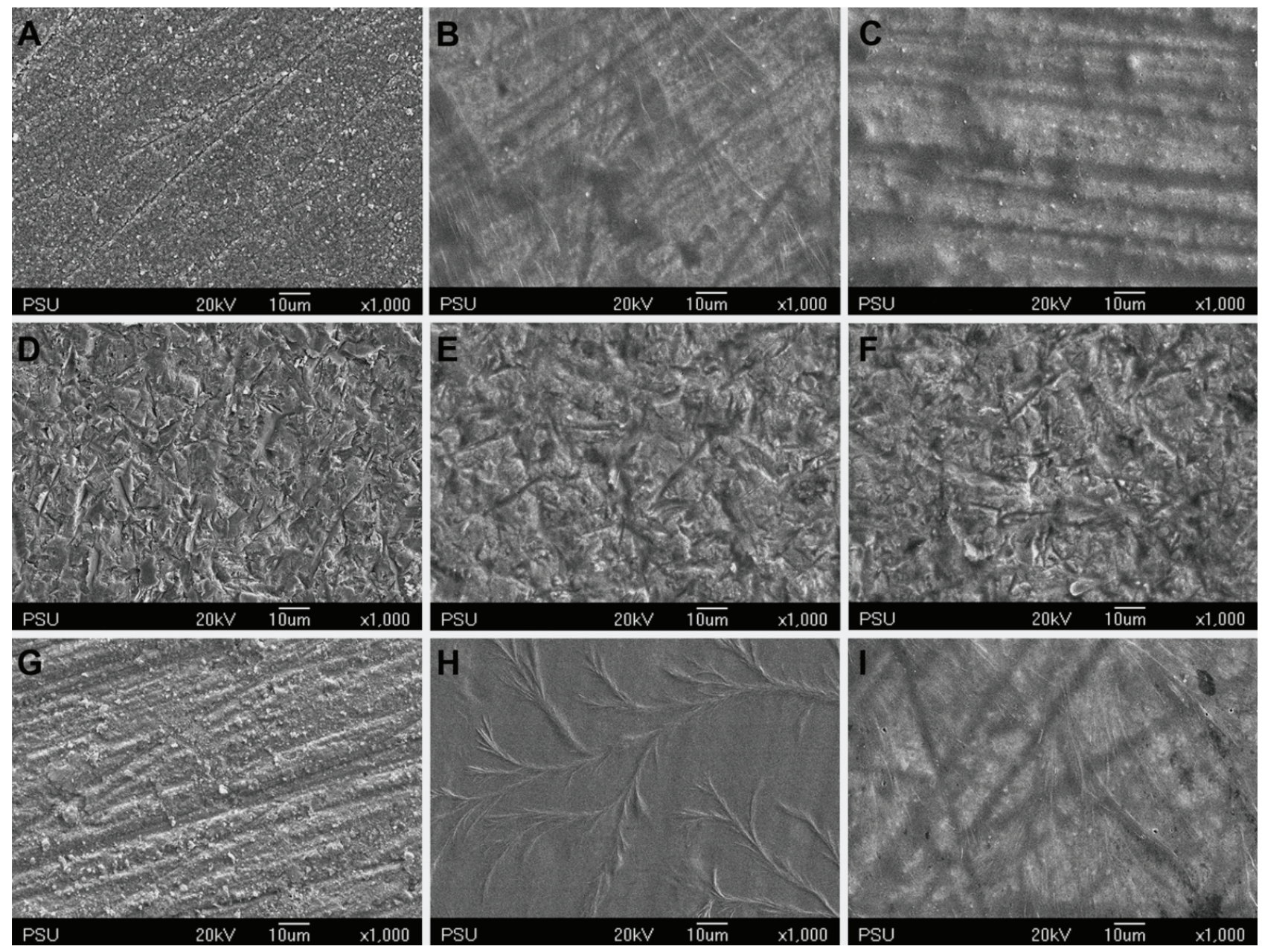

Figure 1 - SEM results of zirconia ceramic specimens (original magnification x1000). (A) Control group. (B) Clearfil Ceramic primer group. (C) Z-Prime Plus primer group. (D) Sandblasted with $50 \mu \mathrm{m} \mathrm{Al}_{2} \mathrm{O}_{3}$. (E) Sandblasted with $50 \mu \mathrm{m} \mathrm{Al}_{2} \mathrm{O}_{3}$ and coated with Clearfil Ceramic primer group. (F) Sandblasted with $50 \mu \mathrm{m} \mathrm{Al}_{2} \mathrm{O}_{3}$ and coated with Z-Prime Plus primer group. (G) GaAlAs diode laser group. (H) GaAIAs diode laser and coated with Clearfil Ceramic primer group. (I) GaAIAs diode laser and coated with Z-Prime Plus primer group.

\section{DISCUSSION}

The aging test or thermocycling by water immersion and temperature change is an important step in studying the effect of zirconia ceramic surface treatments on their durability on bonding to resin composites, by simulating oral conditions that include both saliva moisture and temperature changes from daily consumption habits [16,17]. Previous studies have presented that long term adhesion between zirconia ceramic and resin composite decreased after thermocycling $[18,19]$. A study by Gale and Darvell [20] showed that 10,000 thermocycles could be equivalent to 1 year on oral environment. Therefore, the present study used 2,500 thermocycles which could be equivalent to a 3-month period in an oral condition. The control group showed adhesive failure after a temperature change at $5^{\circ} \mathrm{C}$ and $55^{\circ} \mathrm{C}$ for 2,500 cycles. Due to the lack of both microscopic and chemical attachments, there was water penetration and deterioration the adhesion [21].

Even though the challenges of shear bond strength test included higher bond strengths increased due to cohesive failure in the substrates and non-uniform stress distributions along tested interfaces [22], this study intended to use 
shear bond strength test rather than micro-shear bond strength test due to numerous advantages such as ease of specimen preparation, simple test protocol, simplicity, and reproducible. While micro-shear bond strength test has been introduced to evaluate the bond strength of small area of substrates $\left(1 \mathrm{~mm}^{2}\right.$ or less) to adhesives $[23,24]$. Some studies have reported its disadvantages, namely a technically sensitive procedure, more time consuming, and worse representing shear bond strength than shear bond strength test $[22,25]$.

These present results suggest the hypothesis that shear bond strength is determined not only by surface roughness but also by other factors. A factor that could probably affect the bond strength is the treatment with primer compounds. Primers are an substance which have functional groups such as 4-META (4-methacryloxyethyl trimellitate anhydride), 10-MDP (10-Methacryloyloxydecyl dihydrogen phosphate), MEPS (methacryloyloxyalkyl thiophosphate derivative), and VBATDT (6-(4-vinylbenzyl-n-propyl) a mino-1,3,5trizaine-2,4-dithiol) that can chemically attach to the oxide layer of zirconia ceramic surfaces $[5,26]$. The results of this study showed that Clearfil Ceramic primer products with the MDP functional group and Z-Prime Plus primer, which has an organophosphate functional group mixed with carboxylic acid, can increase the shear bond strength between zirconia ceramic and resin composite when compared to the control group. The MDP functional group has three components, namely the methacrylate group that can react with the polymerization of the resin monomer, a group of dihydrogen phosphate that promotes chemical attachment to the zirconium oxide layer on the surface, and the last decyl group is a hydrophobic element that is able to form a protective barrier for water penetration into the boundary between the dihydrogen phosphate group and the zirconium oxide layer [27]. All these three components of MDP promoted higher shear bond strength after thermocycles in the Clearfil Ceramic primer group than Z-Prime Plus, which has an organophosphate functional group mixed with carboxylic acid, but it was not a significant difference. These results corresponded with the mode of failure with a stereomicroscope, where the Clearfil Ceramic primer group (Group PC) showed $80 \%$ adhesive failure and $20 \%$ combination failure, while the Z-Prime Plus group (Group PZ) presented 100\% adhesive failure, which showed a lower shear bond strength.

Surface treatment by sandblasting with aluminum oxide powder is another method that has been used for a long time in metalceramic restorations. Although, initially, there is a concern about the effect of sandblasting on the phase change of zirconia ceramic from the tetragonal to monoclinic phase and that it reduces the strength. However, many studies have supported the improvement of mechanical properties by sandblasting $[18,28]$. There is also no clinical evidence to confirm the adverse effects of this method [29]. The present study found that surface treatment by sandblasting increased the shear bond strength between zirconia ceramic and resin composite (Group S), which were higher than specimens treated by Z-Prime Plus (Group PZ) but lower than those treated by the Clearfil Ceramic primer group (Group PC), corresponding with other studies $[5,16]$. When evaluating the surface topography of zirconia ceramics after sandblasting by SEM, it was found that the sandblasted surfaces caused rough surface and also increased surface area $[30,31]$. This is one factor that promotes the adhesion between both materials, but the average shear bond strength was lower than Clearfil Ceramic primer groups. This means that micromechanical retention alone was not enough for bonding between zirconia ceramic and resin composite after 2,500 thermocycles because there was no chemical attachment, which allows water penetration and disruption on the adhesion ability, according to Christoforides et al. [17]

Most of the previous studies have supported surface treatment by a combination of sandblasting with aluminum oxide and primers where the bond strength does not 
decrease by thermocycles [19,21,32]. The present study showed the same results where combined surface treatment by sandblasting and primers provided the highest average shear bond strength. The mode of failures also showed the most combination failure. Surface treatment of zirconia ceramic by sandblasting with aluminum oxide together with primer is an effective surface treatment method to promote adhesion, both in micromechanical retention from alteration of the surface characteristics of zirconia ceramics and chemical retention from functional groups in the adhesive layer between the primer and zirconium dioxide layer $[17,33]$. Also sandblasting rough zirconia ceramic surfaces, increased the contact area and reduced contamination from saliva and oral bacteria [5,34]. In addition, sandblasting can increase surface energy and reduce the contact angle of the zirconia ceramic surface, which promotes wettability of the primer adhesive layer and bonding [35]. These increase the efficiency of the functional group from the primer layer to bond to the zirconium oxide layer in a zirconia ceramic both from MDP in Clearfil Ceramic primer or the carboxylic group in Z-Prime Plus primer.

For surface treatment using a diode laser without a primer, the results showed that shear bond strength slightly increased (Group L) compared to control group. However, when the primer was applied, shear bonding strength was similar to groups with solely primer treatment (Groups PC and PZ). Although previous studies have shown that diode lasers alone do not roughen the zirconia ceramic surface $[12,13]$, this study was still conducted expecting that increased wattage or time of a diode laser combined with a primer would increase the shear bond strength. Yet from the results of this study, shear bond strength still increased in only small quantities. This may require further study by combinations with other surface treatments.

The limitation of this study was that only one zirconia ceramic brand was investigated, so it might not be able to represent all current zirconia products. In addition, even though this study used thermocycle simulation, the oral cavity presents a distinctive environment. For instance, the presence of water, $\mathrm{pH}$ and temperature change in the oral cavity might also significantly influence the properties of the materials and even the thermocycles simulation. Moreover, the present study evaluated the in vitro effect. Therefore, further studies are required to elaborate the effect of surface treatments in vivo.

\section{CONCLUSION}

Under the limitations of this study, it was possible to conclude that surface treatment of zirconia ceramic play an important factor in direct bonding to resin composite. Surface treatment by sandblasting with aluminum oxide combined with ceramic primers (Clearfil Ceramic primer, with MDP functional group or Z-Prime Plus, with organophosphate functional group mixed with carboxylic acid) significantly provided the highest shear bond strength between zirconia ceramic and resin composite.

\section{Conflicts of interest}

The authors have no conflicts of interest relevant to this article.

\section{Acknowledgments}

None.

\section{Funding}

This study was partially supported by Dental Materials Research Unit (Second phase) Fund, Prince of Songkla University.

\section{Regulatory Statement}

None.

\section{REFERENCES}

1. Gautam C, Joyner J, Gautam A, Rao J, Vajtai R. Zirconia based dental ceramics: structure, mechanical properties, biocompatibility and applications. Dalton Trans 2016 Dec;45(48):19194-215. doi:101039/C6DT03484E.

2. Agingu C, Zhang CY, Jiang NW, Cheng H, Özcan M, Yu H. Intraoral repair of chipped or fractured veneered zirconia crowns and fixed dental prosthesis: clinical guidelines based on literature review. J Adh Sci Tech 2018 Feb;32(15):1711-23. doi:10.1080/01694243.2018.1443639. 
3. Schley J, Heussen N, Reich S, Fischer J, Haselhuhn K, Wolfart S, et al. Survival probability of zirconia-based fixed dental prostheses up to $5 \mathrm{yr}$ : a systematic review of the literature. Eur J Oral Sci 2010 0ct;118(5):443-50. do: 10.1111/.j.1600-0722.2010.00767.x.

4. Stangel I, Nathanson D, Hsu CS. Shear strength of the composite bond to etched porcelain. J Dent Res 1987 Sep;66(9):1460-5. doi: 10.1177/00220345870660091001.

5. Yun JY,Ha SR, Lee JB, Kim SH. Effect of sandblasting and various metal primers on the shear bond strength of resin cement to Y-TZP ceramic. Dent Mater 2010 Jun;26(11):650-8. doi:10.1016/.jdental.2010.03.008.

6. Khan AA, AI Kheraif AA, Jamaluddin S, Elsharawy M, Divakar DD. Recent trends in surface treatment methods for bonding composite cement to zirconia: a reveiw. J Adhes Dent 2017 Jan;19(1):7-19. doi: 10.3290/j.jad.a37720.

7. Nagaoka N, Yoshihara K, Tamada Y, Yoshida Y, Meerbeek BV. Ultrastructure and bonding properties of tribochemical silica-coated zirconia. Dent Mater J. 2019 Feb;38(1):107-13. doi:10.4012/dmj.2017-397.

8. Kasraei S, Atefat M, Beheshti M, Safavi N, Mojtahedi M, Rezaei-Soufi L .Effect of surface treatment with carbon dioxide (CO2) laser on bond strength between cement resin and zirconia. J Lasers Med Sci 2014 Summer;5(3):115-20. doi: 10.22037/jms.v5i3.6438.

9. Usumez A, Hamdemirci N, Koroglu BY, Simsek I, Parlar O, Sari T. Bond strength of resin cement to zirconia ceramic with different surface treatments. Lasers Med Sci 2013 Jan;28(1):259-66. doi: 10.1007/s10103-012$1136-\mathrm{x}$.

10. Sofi LR, Fekrazad R, Akbarzadeh M, Maleki M. Effect of Er:YAG Laser, sandblast and several types of universal bonding on shear bond strength of zirconia ceramic to composite resin. J Contemp Dent Pract 2018 Oct;19(10):1246-53. doi:10.5005/JP-JOURNALS-10024-2412.

11. Tokar E, Polat S, Ozturk C. Repair bond strength of composite to Er,Cr:YSGG laser irradiated zirconia and porcelain surfaces. Biomed J 2019 Jun;42(3):193-9. doi: 10.1016/.j.j.2019.02.001.

12. Stubinger S, Homann F, Etter C, Miskiewicz M, Wieland M, Sader R. Effect of Er:YAG, CO2 and diode laser irradiation on surface properties of zirconia endosseous dental implants. Lasers Surg Med 2008 Mar:40(3):223-8. doi: 10.1002/sm.20614

13. Kushima SS, Nagasawa M, Shibli JA, Brugnera A Jr, Rodrigues JA, Cassoni A. Evaluation of temperature and roughness alteration of diode laser irradiation of zirconia and titanium for peri-implantitis treatment. Photomed Laser Surg 2016 May;34(5):194-9. doi: 10.1089/pho.2015.4026.

14. Kriebel M. Effect of Er,Cr: YSGG and diode laser treatment on surface properties of 3Y-TZP for dental applications [thesis]. Ohio: Ohio State University; 2010

15. Kukiattrakoon B, Thammasitboon K. The effect of different etching times of acidulated phosphate fluoride gel on the shear bond strength of high-leucite ceramics bonded to composite resin. J Prosthet Dent 2007 Jul;98(1):17-23. doi:10.1016/S0022-3913(07)60033-X

16. Komine F, Kobayashi K, Blatz MB, Fushiki R, Koizuka M, Taguchi K, et al. Durability of bond between an indirect composite veneering material and zirconium dioxide ceramics. Acta Odontol Scand 2013 May-Jul;71(4):457-63. doi: 10.3290/j.jad.a22711.

17. Cristoforides P,Amaral R, May L, Bottino M, Valandro L. Composite resin to yttria stabilized tetragonal zirconia polycrystal bonding: comparison of repair methods. Oper Dent 2012 May-Jun;37(3):263-71. do: 10.2341/11-193-L.
18. Qeblawi DM, Munoz CA, Brewer JD, Monaco EA. The effect of zirconia surface treatment on flexural strength and shear bond strength to a resin cement. JProsthet Dent 2010 Apr;103(4):210-20. doi:10.1016/S00223913(10)60033-9.

19. Attia A, Kern M. Long-term resin bonding to zirconia ceramic with a new universal primer. J Prosthet Dent 2011 Nov;106(5):319-27. doi: 10.1016/S00223913(11)60137-6.

20. Gale M, Darvell B. Thermal cycling procedures for laboratory testing of dental restorations. J Dent 1999 Feb;27(2):89-99. doi: 10.1016/s03005712(98)00037-2.

21. Blatz MB, Sadan A, Martin J, Lang B. In vitro evaluation of shear bond strengths of resin to densely-sintered high purity zirconium-oxide ceramic after long-term storage and thermal cycling. J Prosthet Dent 2004 Apr;91(4):356-62. doi:10.1016/.jprosdent.2004.02.001.

22. Placido E, Meira JB, Lima RG, Muench A, de Souza RM, Ballester RY. Shear versus micro-shear bond strength test: a finite element stress analysis. Dent Mater 2007 Sep;23(9):1086-92. doi: 10.1016/j.dental.2006.10.002.

23. Phrukkanon S, Burrow MF, Tyas MJ. Effect of cross-sectional surface area on bond strengths between resin and dentin. Dent Mater 1998 Mar;14(2):1208. doi: 10.1016/s0109-5641(98)00018-9.

24. Armstrong S, Geraldeli S, Maia R, Raposo LH, Soares CJ, Yamagawa J. Adhesion to tooth structure: a critical review of "micro" bond strength test methods. Dent Mater 2010 Feb;26(2):e50-62. doi: 10.1016/j.dental.2009.11.155.

25. Harnirattisai C, Roengrungreang P, Rangsisiripaiboon U, Senawongse P. Shear and micro-shear bond strengths of four self-etching adhesives measured immediately and 24 hours after application. Dent Mater J 2012 Sep;31(5):779-87. doi: 10.4012/dmj.2012-013.

26. Souza GM, Thompson VP, Braga RR. Effect of metal primers on microtensile bond strength between zirconia and resin cements. J Prosthet Dent. 2011 May;105(11):296-303. doi: 101016/S0022-3913(11)60055-3.

27. Ikemura K, Tanaka H, Fujii T, Deguchi M, Endo T,Kadoma Y. Development of a new single-bottle multi-purpose primer for bonding to dental porcelain, alumina, zirconia, and dental gold alloy. Dent Mater J 2011 Jul;30(4):478-84 . doi: 10.4012/dmi.2010-182.

28. Fonseca RG, Rached F0, Reis JN, Rambaldi E, Baldissara P.Effect of particle size on the flexural strength and phase transformation of an airborneparticle abraded yttria-stabilized tetragonal zirconia polycrystal ceramic. J Prosthet Dent 2013 Dec;110(6):510-4. doi:10.1016/.jprosdent.2013.07.007.

29. Koenig V, Vanheusden AJ, Goff SO, Mainjot AK. Clinical risk factors related to failures with zirconia-based restorations: an up to 9-year retrospective study. JDent2013 Dec;41(12):1164-74. doi:10.1016/j.jdent.2013.10.009.

30. Ozcan M, Valandro LF, Pereira SM, Amaral R, Bottino MA, Pekkan G. Effect of surface conditioning modalities on the repair bond strength of resin composite to the zirconia core/veneering ceramic complex. J Adhes Dent 2013 Jun;15(3):207-10. doi: 10.3290/j.jad.a29717.

31. ReD, Augusti D, Augusti G, Giovannetti A. Early bond strength to lowpressure sandblasted zirconia: evaluation of a self-adhesive cement. Eur J Esthet Dent 2012 Summer;7(2):164-75.

32. Papia E, Larsson C, Toit MD, Steyern VV. Bonding between oxide ceramics and adhesive cement systems: a systematic review. J Biomed Mater Res Part B: Appl Biomater 2014 Feb;102(3):395-413. doi: 10.1002/jbm.b.33013. 
33. Koizumi H, Nakayama D, Komine F, Blatz MB, Matsumura H. Bonding of resin-based luting cements to zirconia with and without the use of ceramic priming agents. J Adhes Dent 2012 Aug;14(4):385-92. doi: 10.3290/j.jad. a22711

34. Sarmento HR, Campos F, Sousa RS, Machado JP, Souza RO, Bottino MA, et al. Influence of air-particle deposition protocols on the surface topography and adhesion of resin cement to zirconia. Acta Odontol Scand 2014 Jul;72(5):346-53. doi: 10.3109/00016357.2013.837958.
35. Chen L Shen H, Suh BI. Effect of incorporating BisGMA resin on the bonding properties of silane and zirconia primers. JProsthet Dent 2013 Nov;110(5):402-7. doi:10.1016/.jprosdent.2013.04.005.

\section{Boonlert Kukiattrakoon}

\section{(Corresponding address)}

Department of Conservative Dentistry and Dental Materials Research Unit (Second phase), Faculty of Dentistry, Prince of Songkla University, Kanchanavanich Rd., Hat

Yai, Songkhla, Thailand, 90112 